\title{
抽水植物, 沈水植物が河川水質に与える影響
}

\author{
関根雅彦*.浮田正夫**.中西 弘**. \\ 城田久岳***
}

\begin{abstract}
実河川において抽水植物, 沈水植物が河川水質に与える影響を調査した。その結果, 抽 水植物は平水時には水質浄化に奇与していないことが明らかになった．抽水植物の水質浄 化効果は増水時の堆積作用が主要なものである. 一方沈水植物は群落全体としては平水時 水質净化に寄与している。しかし増水時には剝離流出することにより下流域への負荷量削 減効果は小さい. 抽水植物, 沈水植物の存在意義は, 水質浄化面ではなく, 生態系の保全 という観点から評価する必要がある.
\end{abstract}

Key Words : river water quality, emersed plants, submerged plants

\section{1. 序 論}

アオコの大量発生や赤潮等に代表される富栄養化問題 の主たる原因は生活排水であるという考え方はすでに定 着しており，水域に流入する栄養塩負荷量をいかに低減 するかが目下の課題である.このための対策として，下 水道, 浄化槽等の人工的な施設による処理が進められて いる一方で, 自然界にもともと存在した自浄作用を高度 に利用しようとする動きもある．自然界の自浄作用の利 用という考え方は，近年の環境問題に対する関心の高ま りに伴い, 地球に優しい技術として一般に受け入れられ やすいものとなっており,これに関連して「生態工学」, 「自然型工法」等の新しいキーワード1)が定着しつつある.

水域での自浄作用を利用した技術としては, 礫間接触 酸化等とならび, 水生植物の利用が検討されることが多 い. 水生植物による水質改善は古くから述べられている が, 多くは湖沼等の静水域で, ホテイアオイ等の浮漂植 物を取り扱ったものである2) 4). 浮漂植物は栄養塩を直 接水体から吸収するという意味で, 最も明確に水質浄化 に寄与していると言える. また静水域であれば植物体と 水の接触時間が長く, 効果を期待しやすい. 抽水植物は もっぱら根から栄養塩を吸収していると考えられるため, 浮漂植物ほど単純に浄化効果を評価できないが, 植物体 内の栄養塩は間違いなく水域内から吸収したものである という意味で水質浄化に寄与すると期待されるのが普通

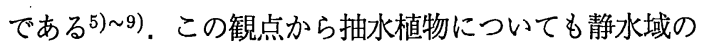
岸辺での水質浄化についての詳しい研究10)がある. 河川 などの流水においては, 静水域ほど研究されていないが, 抽水植物を排水処理に用いる研究11) 14)や，河川内にお ける浄化の可能性に言及している研究15)が見られる. 近

\footnotetext{
* 正会員 工博 山口大学講師 工学部社会建設工学科 （テ 755 宇部市常盤台 2557）

** 正会員 工博 山口大学教授 工学部社会建設工学科

*** 工修 宇部短期大学講師
}

年では水質浄化のみならず，抽水植物による流速低減効 果に着目し, 河岸の保護工としての利用16),17) まで検討さ れている.

しかし一方では, 水生植物栽培法は収穫量に比較して 栄養塩除去量が少なく，また刈り取りに伴う回収が膨大 になるとの指摘9),18)や，実湖沼におけるホテイアオイに よる水質浄化施設において水質の浄化が認められないと (う報告4)等, その効果を疑問視する意見も少数ながら 見受けられる.

水生植物帯は, 植物, 魚類から昆虫, バクテリアにい たる多様な生物の存在, 底泥との物質交換など, 複雑な 生態系を持っている．このため, 実験室で測定された純 粋な水生植物による水質浄化速度だけではとらえられな い水質変化が起こっていると考兄られる.

本研究は，これまであまり研究されていない流水中の 抽水植物帯, 沈水植物帯に焦点を絞り, 実河川において 底泥や種々の生物の効果を包括した水生植物帯全体が河 川水質に与える影響を明らかにし，これら水生植物の河 川水質浄化法としての利用可能性を評価しょうとするも のである.

\section{2. 抽水植物の影響}

\section{(1) 調查河川}

調査河川は山口県宇部市の真締川である。調査期間は 1989 年 4 月から 12 月および 1990 年 5 月から 12 月であ る. 水質調査の対象区域を図-1に示す. 対象区域は全長 $831 \mathrm{~m}$ の直線区間で, 途中流入はない. 河床勾配は 0.09$0.17 \%$ (平均 $0.13 \%$ ), 川幅は $10-20 \mathrm{~m}_{\mathrm{L}}$ (平均 $13 \mathrm{~m}$ ) であ る.この区域の上流端を上流探水地点, 上流から $373 \mathrm{~m}$ の位置にある堰を中流採水地点, 下流端を下流採水地点 とした. 以下では中流採水地点より上部を上流部, 下部 を下流部と呼ぶ. 6 月 1 日から 10 月 1 日まで堰のため上 流部の水位が高くなる.下流採水地点の直下には伏せ越 


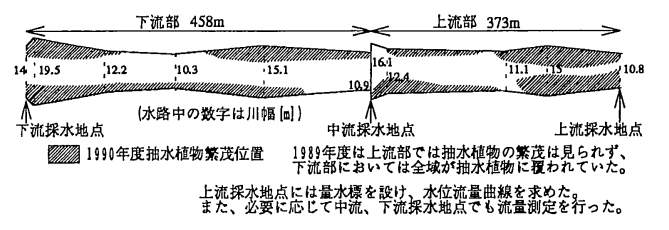

図-1 真締川調査地点

しの暗渠があり，これが堰の働きをして下流部では通年 水位が高い. 上流部は 1989 年 2 月から 3 月にかけて河床 整備が行われ，4月時点ではほとんど水生植物はみられ なかった.下流部においてはほほ全域においてガマ, ヨ 等の抽水植物が河床を覆い, 河岸付近ではススキ等が 繁茂していた. 主流部は狭い水みちとなり，植物の密度 が小さくなっていたが，抽水植物帯のほほ全域が冠水し ていた，河床状態は，上流部においては砂利，下流部で は粘土質の土壇の上に多量の泥が堆積していた. 1989 年 7月14日には, 下流部において人手により抽水植物が刚 り取られたが，根部は残されたため植物相は急速に回復 した. 1989 年 10 月 13 日にはパワーショベルが下流部河 床に入り, 堆積物とともに植物も除去された. 一方上流 部では, 1989 年中は植物の繁茂はごく一部に留まったも のの, 1990 年度にはほほ全面でヨシ, ガマが繁茂した.

（2）水生植物量の季節変化

a) 抽水植物量

1989 年度の植物量については, 著者らが 1984 年から 1985 年にかけて同河川を含む数河川で実施した植生密 度調査結果 ${ }^{19)}$ を用いて推定した. 1990 年度については, 1989 年度の河床整備の結果植生密度が小さくなっていた ため, 改めて調査を行なった. 1990 年 5 月から 12 月の間 月 1 回, 調査区間における代表的な抽水植物であるヨシ, ヒメガマ, ガマについて，それぞれの群落において $1 m^{2}$ あたりの植物体本数を計数し, 代表的な 1 本を根部を含 めて採取した. ヨシ群落においては前年度の枯死した植 物体も存在したが, これは計数は行ったが植物量として は計上しなかった. ヨシについては調査区間から約 $300 \mathrm{~m}$ 下流の群落, ガマについては上流部の群落, ヒメガマは 下流部の若い群落から採取した，採取した植物体は，含 有 COD,T-N,T-P を測定した*. この分析結果から, 月 毎の各植物群落の単位面積あたり植物量を決定した.

調査区間全体の植生面積は, 調査時に撮影した河床の 写真から約 $50 \mathrm{~m}$ 毎の河川断面における各植物群落の被 覆率を求め, 区間面積を乗じる事により月毎に推定した. これに先の単位面積あたり植物量を乗じることにより調 查区間全体の植物量を得た。

以上より求めた抽水植物量の季節変化を図-2に示す.

\footnotetext{
* 含有 $\mathrm{COD}$ とは植物体そのものの COD である.
}

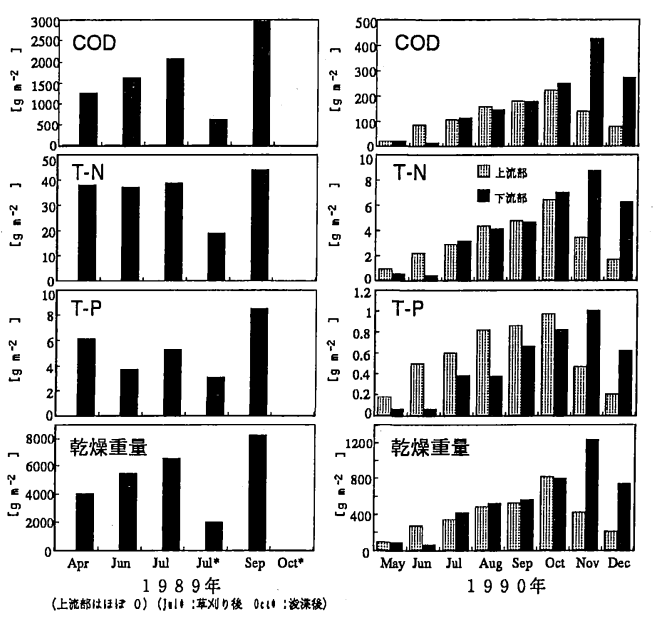

図-2 抽水植物量の季節変化

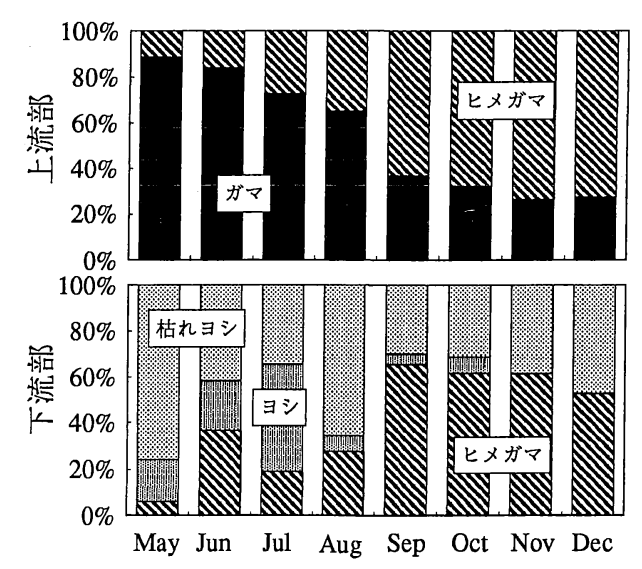

図-3 抽水植物構成比の季節変化 $(\mathrm{COD}$ による)

また, 1990 年度調査に基づく抽水植物構成比の季節変化 を図-3に示す.

\section{b) 総生物量}

植物群落内には, 植物体だけではなく, 魚や昆虫等様々 な生物が生息している.これらの総生物量をヨシ群落に おいて測定した．調査地点は水質調査を行った区間の約 $300 \mathrm{~m}$ 下流である。調査地点は川幅約 $16 \mathrm{~m}$ で, 左岸側約 $6 \mathrm{~m}$ が流水部, 残りの右岸側がヨシを主体とした抽水植 物帯となっている．流水の接する左岸はほぼ鉛直の石組 護岸となって扔り, 植生はない. 右岸はコンクリート傾 斜護岸である. ヨシ群落部分は堆積作用により河床が高 まっており，流水部に接する約 $1 \mathrm{~m}$ の範囲を除いて平水時 には地盤高と水面高がほほ一致しており冠水していない.

調査にあたっては流下方向に $10 \mathrm{~m}$ の区間の上下を目の 開き $1.5 \mathrm{~mm}$ の網で仕切り,ささらにその内部を同じ網に 
表-1 総生物量調查結果 $(1990 / 5 / 21)$

\begin{tabular}{|c|ccc|}
\hline & 数量 & 湿重 $(\mathrm{g})$ & 乾重 $(\mathrm{g})$ \\
\hline 水生植物帯 & & & \\
貝 & 2 & 22.2 & 2.26 \\
エビ & 3 & 6.09 & 1.72 \\
魚 & 11 & 0.136 & 0.017 \\
昆虫 & 7 & 1.84 & 0.34 \\
蛙 & 1 & 600 & - \\
亀 & 1 & 350 & - \\
\hline 流水部 & & & \\
魚（タナゴ) & 1 & 2.71 & 0.62 \\
\hline
\end{tabular}

(水生植物帯約 $100 \mathrm{~m}^{2}$, 流水部約 $60 \mathrm{~m}^{2}$ あたり. ただし水生植 物帯の非冠水部約 $80 m^{2}$ は実質的には調査していない．）

よってヨシ群落と流水部に分けた．網を張る作業により 生物が区間外に逃げることを避けるため, 網は調査日の 前日に川底に沈め, 調査当日には網を引き上げることに より直ちに網を張れるようにした. 区間内の生物は手網 により全量採取を目指した。調査結果を表-1に示す. 表 -1より, 植物帯には流水部の 10 倍以上の動物が存在し ていることが判明した．抽水植物帯は小動物の格好の生 息場となっている.

以上の調査を通じて，ヨシ群落中に多数のカニ等の生 息が観察された. しかしながら, 本調査ではヨシ群落を 刚り取らずに作業を行ったため，これらを計数すること ができなかったこのの省に基づき，ヨシの刚り取りも含 め, 完全に植物帯内生物を採取する調査を実施した. 本 調査では流水部生物量は調査せず, 非冠水部を含むヨシ 群落内のみをビニールシートで完全に团い込んだ. 前調 查と同様, ビニールシートは前日あらかじめ河床に設置 した. 調査当日はまずヨシを全量刈り取り, 地上部の全 湿重を測定した. 次いで冠水部, 非冠水部に生息する動 物を全量採取し, 計数, 重量測定を行った. 最後に, 非冠 水部において $25 \times 25 \mathrm{~cm}$ の範囲に存在する根部を全量採 取した. 採取した植物, 動物については, 含有 COD,TN,T-P を測定した. 調査結果を表-2に示す. 表-2より, 抽水植物帯における生物の存在形態としては植物の根が 圧倒的に多く，全体のおよそ $80 \%$ を占ることが判明し た. 動物は地上部植物量の $2 \%(\mathrm{COD})-20 \%$ (T-N,T-P) 程度が存在していた。

\section{(3) 平水時水質への影響}

a) 季節変化

調査期間中ほぼ週 1 回, 上, 中, 下流採水地点にて $1 l$ 採水し，同時に水温と流量を記録した，流量に関しては 採水地点間でほとんど違いが見られなかった.このため, 上流採水地点に量水標を設置して水位一流量曲線を作成
表-2 総生物量調查結果 $(1990 / 9 / 7)$

\begin{tabular}{|c|cccccc|}
\hline & \multicolumn{2}{|c|}{ COD } & \multicolumn{2}{c|}{$\mathrm{T}-\mathrm{P}$} & \multicolumn{2}{c|}{$\mathrm{T}-\mathrm{N}$} \\
& $(\mathrm{g})$ & $(\%)$ & $(\mathrm{g})$ & $(\%)$ & $(\mathrm{g})$ & $(\%)$ \\
\hline 生きたヨシ & 2300 & $(5)$ & 13.3 & $(10)$ & 111.6 & $(11)$ \\
枯れたヨシ & 4210 & $(9)$ & 8.0 & $(6)$ & 84.3 & $(8)$ \\
ガマ & 680 & $(1)$ & 3.6 & $(3)$ & 15.5 & $(1)$ \\
根 & 38100 & $(84)$ & 107.6 & $(78)$ & 799.2 & $(76)$ \\
カニ & 98.2 & $(0)$ & 4.0 & $(3)$ & 30.6 & $(3)$ \\
魚(大) & 23.1 & $(1)$ & 1.0 & $(1)$ & 5.4 & $(1)$ \\
魚 (小) & 1.1 & $(0)$ & 0.1 & $(0)$ & 0.3 & $(0)$ \\
オタマジャクシ & 0.96 & $(0)$ & 0.09 & $(0)$ & 2.0 & $(0)$ \\
\hline
\end{tabular}

(水生植物帯約 $100 \mathrm{~m}^{2}$ あたり.)

表-3 抽水植物帯季節変化調查結果の概要

\begin{tabular}{|c|c|c|c|c|c|c|}
\hline & \multicolumn{3}{|c|}{1989 年度 } & \multicolumn{3}{|c|}{1990 年度 } \\
\hline 流量 & \multicolumn{3}{|c|}{0.194} & \multicolumn{3}{|c|}{0.223} \\
\hline$\left[\mathrm{m}^{3} / \mathrm{s}\right]$ & \multicolumn{3}{|c|}{$(0.097)$} & \multicolumn{3}{|c|}{$(0.144)$} \\
\hline & 上流部 & 下流部 & & 上流部 & 下流部 & \\
\hline 滞留時間 & 2.36 & 3.44 & & 2.49 & 3.88 & \\
\hline$[h r]$ & (3.71) & (1.97) & & $(2.26)$ & (2.77) & \\
\hline 水質濃度 & 上流 & 中流 & 下流 & 上流 & 中流 & 下流 \\
\hline solCOD & 3.13 & 3.16 & 3.35 & 3.09 & 3.40 & 3.22 \\
\hline$[\mathrm{mg} / \mathrm{l}]$ & $(0.84)$ & $(0.75)$ & $(0.71)$ & $(0.60)$ & $(0.64)$ & $(0.73)$ \\
\hline ssCOD & 0.970 & 0.976 & 1.196 & 0.790 & 0.725 & 1.061 \\
\hline$[\mathrm{mg} / \mathrm{l}]$ & $(0.491)$ & $(0.573)$ & $(0.641)$ & $(0.429)$ & $(0.191)$ & $(0.921)$ \\
\hline solT-N & 0.881 & 0.779 & 0.739 & 0.712 & 0.786 & 0.734 \\
\hline$[\mathrm{mg} / \mathrm{l}]$ & $(0.158)$ & $(0.158)$ & $(0.157)$ & $(0.305)$ & $(0.245)$ & $(0.281)$ \\
\hline ssT-N & 0.100 & 0.101 & 0.113 & 0.129 & 0.123 & 0.180 \\
\hline$[\mathrm{mg} / \mathrm{l}]$ & $(0.071)$ & $(0.067)$ & $(0.080)$ & $(0.181)$ & $(0.047)$ & $(0.122)$ \\
\hline solT-P & 59.2 & 46.2 & 45.0 & 46.7 & 44.7 & 37.5 \\
\hline$[\mu g / l]$ & $(35.9)$ & (10.3) & $(10.7)$ & $(10.4)$ & $(8: 6)$ & $(11.3)$ \\
\hline ssT-P & 26.3 & 32.2 & 42.9 & 20.5 & 24.5 & 29.7 \\
\hline$[\mu g / l]$ & $(20.0)$ & (28.7) & $(26.3)$ & $(9.6)$ & (8.9) & (18.0) \\
\hline
\end{tabular}

し, 特に事情のない場合は上流採水地点の水位を測定す ることにより流量を得た。また, 滞留時間を得るため, あらかじめ調查区間の河床断面を約 $50 \mathrm{~m}$ おきに測量し, 各採水地点の水位, 流量, 河床の,粗度係数を用いて水面 形を算出し, 調査区間の存在水量を推定した. 水位一流 量曲線や存在水量は, 堰上げや浚渫が行われた場合には そのつど更新した. なお, 滞留時間の推定は以下の解析 の基礎となるため, 別に上流, 中流採水点より食塩を流 下させて中流, 下流採水点にて電気伝導度計により塩素 イオン濃度の時間変化を測定し,この測定值が拡散を伴 う塩素イオン流下の解析解と一致するよう解析解に用い る拡散係数および存在水量を調整することにより推定存 在水量に補正を施した ${ }^{20)}$. また, 精度の高い水質データ を得ることを目的として，1989 年 4 月 24-25 日，7月 3 - 4 日，7月 $24-25$ 日， 12 月 6-7 日の 4 回， 24 時間 調査を実施した. 24 時間調査では各採水点にて 1 時間毎 に $1 l$ の採水, 流量, 水温測定を行った. 調査時の水質濃 度の概要を表-3,4に示す.

一般に, 河川のある区間における水質濃度の変化には 次式が適用されることが多い. 
表-4 抽水植物帯 24 時間調查結果の概要

\begin{tabular}{|c|c|c|c|c|c|c|c|c|c|c|c|c|c|c|c|}
\hline & \multirow{3}{*}{\multicolumn{2}{|c|}{$\begin{array}{c}\text { 流量 } \\
m^{3} \cdot \sec ^{-1}\end{array}$}} & \multirow{2}{*}{\multicolumn{2}{|c|}{ 水温 ${ }^{\circ} \mathrm{C}$}} & \multirow{2}{*}{\multicolumn{3}{|c|}{ 滞留時間 $\mathrm{hr}$}} & \multirow{2}{*}{\multicolumn{3}{|c|}{ 水量 $m^{3}$}} & \multirow{2}{*}{\multicolumn{2}{|c|}{ 水深 $m$}} & \multirow{2}{*}{\multicolumn{3}{|c|}{ 下流部植物量 $g \cdot m^{-2} \cdot m^{-1}$}} \\
\hline & & & & & & & & & & & & & & & \\
\hline & & & 上流部 & 下流部 & \multicolumn{2}{|c|}{ 上流部 } & 下流部 & 上流部 & \multicolumn{2}{|c|}{ 下流部 } & 上流部 & 下流部 & \multicolumn{3}{|c|}{ COD $\quad \mathrm{T}-\mathrm{N} \quad \mathrm{T}-\mathrm{P}$} \\
\hline $4 / 24$ 昼 & \multicolumn{2}{|c|}{0.190} & 16.0 & 16.4 & \multicolumn{2}{|c|}{0.40} & 3.13 & 275 & 2145 & \multicolumn{2}{|r|}{0.10} & 0.37 & 3520 & 102.1 & 15.5 \\
\hline $4 /$ & \multicolumn{2}{|c|}{158} & .7 & 11.6 & \multicolumn{2}{|c|}{0.43} & 3.72 & 247 & 2119 & \multicolumn{2}{|r|}{0.09} & 0.37 & 520 & 102.1 & 15.5 \\
\hline $7 / 3$ 昼 & \multicolumn{2}{|c|}{0.245} & 0.4 & 20.5 & \multicolumn{2}{|c|}{1.87} & 2.54 & 1653 & 2239 & \multicolumn{2}{|r|}{0.46} & 0.39 & 5245 & 106.0 & 12.9 \\
\hline $7 / 3$ 夜 & \multicolumn{2}{|c|}{0.200} & 9.5 & 19.1 & \multicolumn{2}{|c|}{2.24} & 2.64 & 613 & 190 & & 0.45 & 0.33 & 245 & 106.0 & 12.9 \\
\hline $7 / 24$ 昼 & & & .0 & 30.0 & & & 3.74 & 1600 & 154 & & 0.45 & 0.2 & 586 & 78.6 & 12.6 \\
\hline $7 / 24$ 夜 & & & 4.2 & 24.9 & & & 4.43 & 1580 & 145 & & 0.44 & 0. & 2586 & 78.6 & 12.6 \\
\hline 12 & & & 11.6 & 12.5 & & & 3.51 & 186 & 109 & & 0.07 & 0. & 0 & 0.0 & 0.0 \\
\hline $12 /$ & & & 8.5 & 8.6 & & & 3.98 & 186 & 1090 & & 0.07 & 0.178 & 0 & 0.0 & 0.0 \\
\hline & & 㞀度 & $\overline{7}^{-1}$ & 中流澺 & 零度 & $l^{-1}$ & & 震度 $m g$. & $\overline{7^{-}}$ & & 㐬部減少倸 & $h r^{-1}$ & & 充部減少係数 & $\overline{h r^{-1}}$ \\
\hline & OD & $\mathrm{T}-\mathrm{N}$ & $T-P$ & $\mathrm{COD}$ & & $\mathrm{T}-\mathrm{P}$ & $\mathrm{COD}$ & $\mathrm{T}-\mathrm{N}$ & T-P & OD & $\mathrm{T}-\mathrm{N}$ & $T-F$ & $\mathrm{COD}$ & $\mathrm{T}-\mathrm{N}$ & T-P \\
\hline 04/24冝 & 4.51 & 0.96 & 0.097 & 4.36 & & 0.083 & 4.59 & 0.923 & 0.085 & & 0.108 & 0.3 & -0.017 & -0.001 & -0.009 \\
\hline & & 0.929 & & & & & 3. & & & & & & & & \\
\hline & & & & & & & 4. & 25 & & & 0.00 & & -0.022 & 0. & 0.060 \\
\hline & & & & & & & & & & & 0.062 & & & & 0.018 \\
\hline & & & & & & & 4. & & & & & -0.016 & & -0.001 & -0.046 \\
\hline & & 0 & & & & & & 00 & 0. & & 0. & ( & -0.040 & 0.026 & -0.008 \\
\hline & & 1.12 & 0.1 & 3.86 & 1.022 & & 3.75 & 0.923 & $0.0 \mathrm{rr}$ & & & 0.282 & 0.008 & 0.029 & 0.044 \\
\hline $12 / 06$ 夜 & 3.09 & 0.951 & 0.069 & 2.74 & 0.867 & 0.057 & 2.90 & 0.852 & 0.062 & 0.180 & 0.138 & 0.274 & -0.015 & 0.004 & -0.021 \\
\hline
\end{tabular}

(水質濃度，流量，水温は，1 時間毎の測定値を 6 時から 17 時までを昼, 18 時から 5 時までを夜として平均している.

下流部植物量は単位面積あたり植物量を水深で除したもので, 式 (3)の $B_{p} / h$ に対応している．)

$$
\begin{aligned}
C & =C_{0} \exp (-k t) \\
k & =-\frac{1}{t} \log \left(\frac{C}{C_{0}}\right)
\end{aligned}
$$

ここにC:下流濃度 $[m g / l], C_{0}$ : 上流濃度 $[m g / l], t:$ 滞留時間 $[$ hour $], k:$ 減少係数 $\left[h o u r^{-1}\right]$ である.

$k か ゙$ 正值の場合，その区間で水質濃度が低下した，す なわち浄化されたことになる，本論文では，減少係数が 正值の場合を浄化型，負值の場合を污濁型と呼ぶ.

季節変化調査より求めた減少係数を約 1 力月毎に平均 したものを図-4に示す.

溶存態 (sol) 成分では, T-P,T-N は, 上流部では水生 植物の存在しない1989 年度には浄化型であるのに対し, 水生植物が繁茂しはじめた 1990 年度には污濁型に転じ た.下流部についても，上流部ほど明確ではないが植物 の多い 1989 年度の方が植物の少ない 1990 年度より污濁 型傾向にある. COD ついては, 上流部では季節変化が みられ，4月〜 5 月には污濁型の傾向があり，夏場はや や浄化型に転じると見られる。また，T-P,T-N,COD い ずれについても，1989 年度単年では水生植物除去の直接 の影響は明確には読み取れない。これは水生植物除去作 業による河床の乱れが安定化守るのに時間を要するため であると考えられる。

懸濁態 (ss) 成分では, COD,T-N,T-P とも sol に較べ て減少係数の変動範囲が大きいことがわかる．また, sol ほど明確な傾向は見いだせない。

溶存態と懸濁態を合計した total 成分では, sol 成分の 影響が卓越するため sol に近似した結果となっている.

以上から理解されるように，抽水植物の存在は平水時 水質浄化にほとんど寄与していないか，もしくはいくぶ ん水質污濁に寄与しているように思われる.
表-5 抽水植物帯 24 時間調查結果の最小 2 乗近似による減少 係数

\begin{tabular}{|c|c|c|c|c|c|}
\hline & 相関係数 & $k_{20}$ & $k_{20_{p}}$ & $k_{T}$ & $k_{T_{p}}$ \\
\hline 上流部 & & & & & \\
$\mathrm{COD}$ & 0.11 & $7.19 \times 10^{-2}$ & - & 1.077 & - \\
$\mathrm{T}-\mathrm{N}$ & 0.76 & $5.24 \times 10^{-2}$ & - & 0.912 & - \\
$\mathrm{T}-\mathrm{P}$ & 0.52 & $1.16 \times 10^{-1}$ & - & 0.923 & - \\
\hline 下流部 & & & & & \\
$\mathrm{COD}$ & 0.71 & $-1.28 \times 10^{-2}$ & $-1.76 \times 10^{-6}$ & 1.207 & 1.163 \\
$\mathrm{~T}-\mathrm{N}$ & 0.60 & $2.19 \times 10^{-2}$ & $-2.68 \times 10^{-4}$ & 1.033 & 1.051 \\
$\mathrm{~T}-\mathrm{P}$ & 0.41 & $4.07 \times 10^{-2}$ & $-1.14 \times 10^{-4}$ & 1.159 & 1.000 \\
\hline
\end{tabular}

相関係数は測定 $K$ と計算 $K$ の相関。

b) 植物の影響の抽出

抽水植物が水質に与える影響を抽出するため, 式 (2) の減少係数 $k$ に抽水植物生物量 $B_{p}\left[\mathrm{~g} / \mathrm{m}^{2}\right]$ と水温 $T\left[{ }^{\circ} \mathrm{C}\right]$ を 明示的に導入し，次式のように表記できると仮定した。

$$
K=k_{20} k_{T}^{T-20}+k_{20 p} k_{T_{p}}^{T-20} B_{p} / h
$$

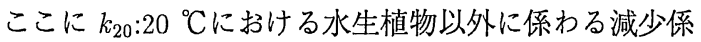
数 $\left[\right.$ hour $\left.{ }^{-1}\right], k_{20 p}: 20{ }^{\circ} \mathrm{C}$ における水生植物に係わる減少 係数 $\left[m^{3} g^{-1} h o u r^{-1}\right], k_{T}$ 水生植物以外に係わる温度係数 $[-], k_{T_{p}}$ : 水生植物に係わる温度係数 $[-], T:$ 水温 $\left[{ }^{\circ} \mathrm{C}\right], h$ : 水 深 $[m]$ である.

解析には 24 時間調查結果を用い, 水温・水質濃度を日 中の 12 時間と夜間の 12 時間でそれぞれ平均して 1 つの データとした．ただし，草刈直後で河床が安定していな かった 1989 年 7 月 24 日のデータは除き, 6 組の $K, T, h$ を求めた. (表-4)これらの值を用い, 最小 2 乗回帰によ り式 (3) の $k_{20}, k_{T}, k_{20 p}, k_{T_{p}}$ を求めた結果を表-5に示す.

表-5より，下流部において COD では水生植物項 $\left(k_{20 p}\right)$, 非水生植物項 $\left(k_{20}\right)$ 共に污濁型となった. T-N,T$\mathrm{P}$ では非水生植物項は浄化型であるが, 水生植物項は污 


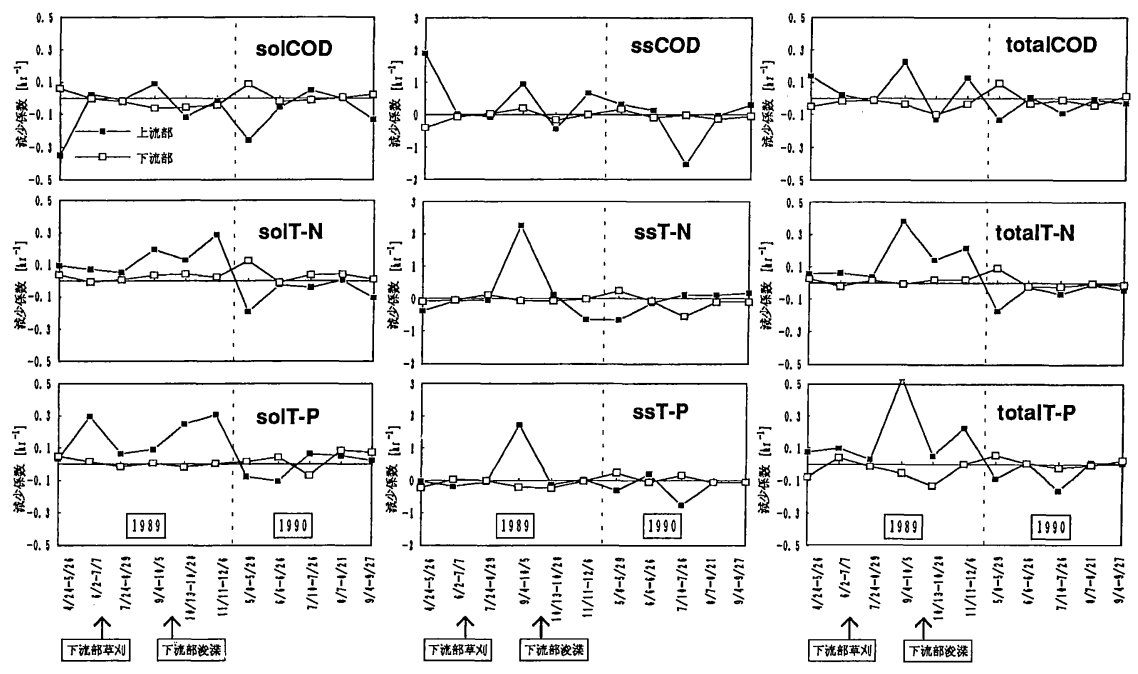

図-4 抽水植物帯水質季節変化調查に抢ける減少係数の変化

表-6 抽水植物帯における非水生植物項と水生植物項の比と 水生植物による污濁物質減少速度

\begin{tabular}{|c|c|c|c|c|}
\hline & \multicolumn{2}{|c|}{$\frac{k_{20_{p}} k_{T_{p}}^{T-20} B_{p} / h}{k_{20} k_{T}^{T-20}}$} & \multicolumn{2}{|c|}{$\begin{array}{c}\text { 水生植物による污濁物質減少速度 } \\
{\left[\mathrm{g} \cdot h r^{-1} m^{-3}\right]} \\
\end{array}$} \\
\hline & $4 / 24$ & $7 / 3$ & $4 / 24$ & $7 / 3$ \\
\hline COD & 0.66 & 0.75 & $-6.79 \times 10^{-3}$ & $-3.08 \times 10^{-2}$ \\
\hline $\mathrm{T}-\mathrm{N}$ & -1.08 & -1.28 & $-1.63 \times 10^{-2}$ & $-2.17 \times 10^{-2}$ \\
\hline $\mathrm{T}-\mathrm{P}$ & -0.15 & -0.04 & $-1.21 \times 10^{-4}$ & $-1.11 \times 10^{-4}$ \\
\hline
\end{tabular}

濁型となった. 非水生植物項においても上流部より下流 部のほうが減少係数が小さいことから, 抽水植物の繁茂 する河床では水生植物以外の生産・分解活動等も活発で あることがうかがわれる。

次に, 非水生植物項に対する水生植物項の比率と水生 植物による污濁物質減少速度を表-6に示す. COD では 水生植物が河床全体の生産活動の約 $40 \%$ を占めている. $\mathrm{T}-\mathrm{N}$ では非水生植物項による浄化分と同程度が水生植 物により污濁されている. T-P では水生植物の影響は $\mathrm{COD}, \mathrm{T}-\mathrm{N}$ に較べると小さい.

細川ら ${ }^{10)}$ が整理した淡水性水生植物の栄養塩取り込み 速度は, ヨシで 200-400 kg-N $\cdot h a^{-1} \cdot y^{-1}, 20-45 k g-$ $\mathrm{P} \cdot h \mathrm{a}^{-1} \cdot \mathrm{y}^{-1}$, ガマで $600-2630 \mathrm{~kg}-\mathrm{N} \cdot h a^{-1} \cdot y^{-1}, 75-$ $403 \mathrm{~kg}-\mathrm{P} \cdot h a^{-1} \cdot y^{-1}$ である. また，枯れヨシからの溶出 速度は窒素について取り込み速度の概略 4 割としてい る. 一方表-6では，水深を $50 \mathrm{~cm}$ と仮定すると抽水植物 帯では $\mathrm{N}, \mathrm{P}$ それぞれ $700-950 \mathrm{~kg}-\mathrm{N} \cdot h a^{-1} \cdot y^{-1}, 5 \mathrm{~kg}-\mathrm{P}$ $\cdot h a^{-1} \cdot y^{-1}$ 程度の栄養塩を放出していることになり，こ れは前述の枯れヨシからの溶出速度とオーダー的に匹敵 するものである.
（4）堆積速度の推定

河道内での懸濁物質堆積速度は, パン法により測定す ることが普通であるが，河床付近の流れを乱すため自然 状態の堆積速度を求めることは難しい. このため, 積年 の堆積物量から堆積速度の推定を試みた。

山口県宇部土木事務所によると, 1989 年度の真締川浚 渫により $629 \mathrm{~m}$ に渡って $1404 \mathrm{~m}^{3}$ の底泥が除去され, こ の時の工費は約 600 万円であった．前回の同様の浚渫は 1986 年度末に実施されているから，3 年間分の堆積物が 除去されたことになる. 1984 年 6 月から 1986 年 1 月に かけて著者らが実施した真締川水生植物帯における底泥 調査結果 5 地点 $\times 5$ 回の平均によると, 約 $15 \mathrm{~cm}$ 厚の底泥 の污濁物質含有量 $(m g / g$-湿泥) は COD:13.7, T-N:0.60, $\mathrm{T}-\mathrm{P}: 0.24$, 比重は $1.36 \mathrm{~g}$-湿泥 $/ \mathrm{cm}^{3}$ であった. これらの值 を底泥の污濁物質含有量の代表值と仮定し, 平均川幅を $12 \mathrm{~m}$ として 3 年間平均の污濁物質堆積速度 $\left(k g \cdot h a^{-1} \cdot y^{-1}\right)$ を概算すると, COD:11600, T-N:510, T-P:220 となる. $\mathrm{N}$ に関しては水生植物帯からの污濁物質放出量に匹敵す る量, また $\mathrm{P} に$ 関しては放出量の約 40 倍が堆積するこ とになる．ただしこの値は植物体自身が倒伏し積層する 分も含んでおり，純粋に懸濁物質のみが堆積したもので はない.

なお，このような観点からは，増水時の水生植物帯上 流端，下流端の水質調査では浄化作用が見られるはずで あるが，実際の水質調査結果では増水時の河川水質は採 水位置による違いや時間変動が大きく, 明確な傾向は見 出せなかった. 


\section{（5） 水質浄化効率の評価}

平水時に水質浄化が見られないことから, 抽水植物帯 では植物体の倒伏および増水時の懸濁物質の堆積により 河床が上昇し，植物体はもっぱら枯死した植物体および 堆積物からなる底泥から栄養塩を吸収して成長している と考元られ. 実際植物帯では 3 年間で $50 \mathrm{~cm}$ 以上も河床 が上昇した部分もある．このため植物体の平水時水質へ の寄与は小さく，かえって植物体の新陳代謝に伴う COD の生産や付着微生物の生産・分解作用により污濁側に作 用している.また，堆積物からの脱窒も考えられるが，植 物帯においては懸濁物質の堆積が堆積物の流出より卓越 しているため堆積物の水体への回帰が少ないと考えられ, 水質浄化への直接の寄与という形では評価できなかった. また，植物帯では脱窒だけでなく窒素固定もありうるこ とにも注意する必要があろう.

以上の考察より，堆積作用が抽水植物帯における主要 な浄化作用であると考え，水生植物帯を処理装置と見な した場合の処理コストを先の真締川の浚渫工事を元に概 算し, 他の水処理費用と比較した. 浚渫はそもそも污濁 物質除去を目的としたものではないため，これを水処理 費用として比較することには無理があるが，一つの参考 にはなろう．堆積物の污濁物質含有量を式 $(4)^{21)}$ により 総酸素要求量 (TOD) に換算する。

$$
\mathrm{TOD}=3 \times \mathrm{COD}+(19.7 / 2) \times \mathrm{T}-\mathrm{N}+(143 / 2) \times \mathrm{T}-\mathrm{P}
$$

これによれば単位湿泥あたりの TOD は $64.2 \mathrm{mg} / \mathrm{g}$-湿 泥となり，真締川の浚渫により除去された底泥の TOD は123ton である. 植物体は最も繁茂している状態で COD:3000,T-N:40,T-P:9 $g \cdot m^{-2}$ 程度であるから (図-2), 0.75ha の河床全体の TOD に換算すると 75ton, 底泥と 合わせて総除去TOD は約 200ton となる. 浚渫工事費は 600 万円であるから処理単価はおよそ 30 円/ $k g$-TOD であ る. 一方, 公共下水道やし尿処理場の処理単価は 220 250 円 $/ k g$-TOD, 食品工業の産業排水処理単価は 39-42 円 $/ k g$-TOD である ${ }^{22)}$ から, 抽水植物帯での堆積作用と浚 渫による堆積物の除去は, 処理コスト的には公共下水道 等のほほ $1 / 8$, 食品工業の排水処理にほぼ匹敵する。

ただし，真締川流域の総排出負荷量 1800 ton-TOD $/ y$ (COD:227,T-N:30,T-P:11ton· $y^{-1}$ より推算 $\left.{ }^{23}\right)$ ) と比較す ると，調査区間 $0.75 h a$ の河床で年間の污濁物質除去率は わずか $4 \%$ 弱にすぎない. 仮に真締川全河床約 $7 h a$ に抽 水植物が繁茂しているとして，全域を浚渫することでよ うやく $35 \%$ 程度の污濁物質除去率となる.

さらに, 水生植物帯における COD 存在量の大部分は 植物の生産によるものであるとも考えられるため，除去 TOD の算定から COD を除外して考えると，同様の計 算により総除去 TOD は約 50ton，処理単価は掞よそ 120 円/ $k g$-TOD とはね上がる. 污濁物質除去率は真締川流域
の総排出負荷量 $1100 t o n-T O D / y$ と比較すると $0.75 h a$ の 河床で $1.6 \%$ ，真締川全域でも $15 \%$ となってしまう。

もちろんこの除去率が毎年維持されるようであれば河 川が埋没していくことになるし，河床の埋没が土砂の流 亡とバランスするようであれば除去率は維持されないこ とになる。

逆に言えば植物体や堆積物による通水断面積の減少と いう治水上困った事態を回復させるための工事が結果的 に污濁物質除去となっているわけであり，抽水植物によ る河川水質の浄化は治水問題と表裏一体であることを認 識する必要がある。

また，抽水植物を積極的に刈り取れば植物体に含まれ ているN,P を河川系外に除去できることははっきりして いるが，それにより植物帯の堆積作用が弱まり，せっか 〈沈殿除去した污濁物質を再流出させてしまう可能性が あることにも注意しなければならない。

\section{3. 沈水植物の影響}

\section{（1）調査河川}

調査河川は山口県山口市の九田川である。調査地点の 川幅は，上流点で約 $4.5 \mathrm{~m}$ ，下流点で $8.5 \mathrm{~m}$ であった．ま た，上流点と下流点間の距離は約 $450 \mathrm{~m}$ であった．調査 は 1989 年 7 月から平成 2 年 7 月にかけて約 1 力月毎に 行った.

\section{（2） 水生植物量の季節変化}

調查区間内の上流点・ 中流点・ 下流点の 3 箇所で川幅 方向に $2 \sim 3$ 本程度の測線を設け, 順次 $50 \mathrm{~cm} \times 50 \mathrm{~cm}$ の 方形枠を置き, 方形枠内での面積当たりの沈水植物の種 類別植被面積を現場に扔ける作図とビデオ記録を基に定 めた．また，それぞれの出現種について，植被率測定点 周辺で平均的な植被密度を示す代表的な株を選び，植被 面積を概測した．次に，その株をなるべく乱さないよう に根こそぎ採取し，蒸留水中で十分すすぐことにより藻 本体と付着物質を分離し，それぞれの含有成分を分析し た. 得られた沈水植物および付着物量の季節変化を図 -5 に, 沈水植物の出現種の構成比の季節変化を図-6に示す.

\section{(3) 平水時水質への影響}

a) 季節変化

調査時の水質濃度 $\left(m g \cdot l^{-1}\right)$ は COD 2.55-7.31(平均 4.44) T-N 0.005-0.547(平均 0.188) T-P 0.076-0.19(平均 0.132) であった. また, 流量 $\left(\mathrm{m}^{3} / \mathrm{s}\right)$ は 0.225-1.16 (平均 0.52 ), 流下時間 $(h r)$ は 0.22-0.82(平均 0.46) であった. 抽水植物と同様に, 式 (2) を用いて求めた減少係数を図 -7に示す．調査頻度が抽水植物のものより少ないため, 同列に論じることはできないが，図-4と比較すると沈水 植物帯の減少係数は抽水植物帯のそれより大きな正值を とっている，すなわち，見掛け上浄化型であるといえる. 

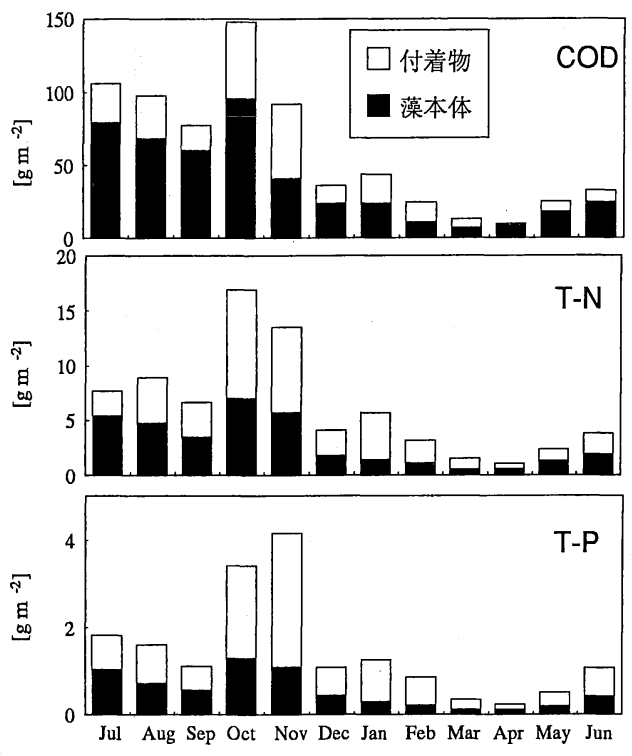

図-5＼cjkstart沈水植物および付着物量の季節変化

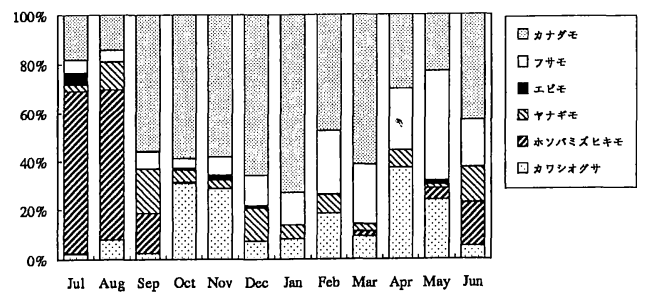

図-6 沈水植物出現種の構成比の季節変化

\section{b) 植物の影響の抽出}

抽水植物の場合と同様に，式 (3) を用いて植物の影響 の抽出を試みた。 ただし, 沈水植物においては付着物量 が植物体に匹敵するほど存在するため, 式(3)の他に，植 物体に加えて付着物をも考慮した式 (5)による解析もあ わせて行った.

$$
K=k_{20} k_{T}^{T-20}+\left(k_{20 p} k_{T_{p}}^{T-20} B_{p}+k_{20 s} k_{T_{s}}^{T-20} B_{s}\right) / h \cdots
$$

ここに $k_{20 s}: 20{ }^{\circ} \mathrm{C}$ に扮ける付着物に係わる減少係数

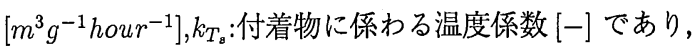
他の記号は式(3) と同様である. 抽水植物の解析にあたっ ては 24 時間調查結果の 12 回の採水の平均を 1 データとし て解析を行ったが，ここでは月 1 回の調查結果をそのまま 1 データとして用いた．式(3)に対しては $k_{20}, k_{T}, k_{20 p}, k_{T_{p}}$ を，式(5)に対してはこれに加えて $k_{20 s}, k_{T_{s}}$ を，それぞれ 最小 2 乗回帰により求めた。結果を表-7に示す.

表-7における相関係数は， $k_{20}, k_{T}, k_{20 p}, k_{T_{p}}, k_{20 s}, k_{T_{s}}$ によ り求めた $k$ と実測值よる $k$ の相関である。これによれば,

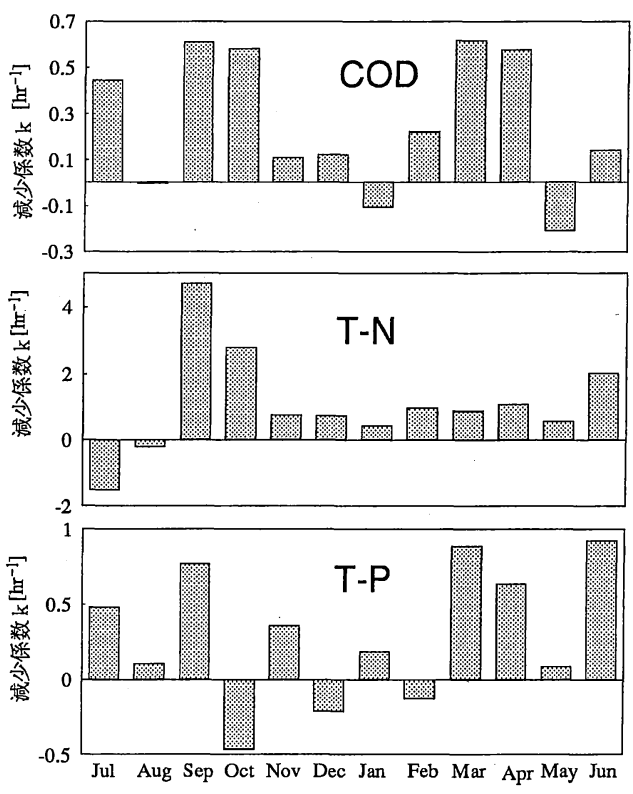

図-7 沈水植物帯の減少係数

式(5)(付着物量を考慮して評価)の方が明らかに相関が高 い. 従って, 沈水植物带では付着物量の評価も大切であ ることがわかる. $k_{20 p}$ と $k_{20 s}$ を比較すると, N,P では植物 体は污濁側に働き，付着物は浄化側に働いており，COD はその逆であることがわかる.これは付着物が栄養塩を 吸収して生長し, 分泌物あるいは本体が流出して COD として検出されるものと考えられる。

次に, 非水生植物項と沈水植物項十付着物項の比, 沈 水植物項と付着物項の比，および沈水植物と付着物によ る污濁物質減少速度の年平均值を表-8に示す.これより， $\mathrm{N}$ では植物体および付着物が水質に大きな影響を及ほし ているが, COD,P では植物体や付着物以外の影響が大 きいと考えられる.ただ, 水生植物量や付着物量と直 接的に関連していなくとも，植物が存在することにより 河床全体の浄化活性の向上に寄与している可能性はある.

\section{（4）水質浄化効率の評価}

抽水植物帯に較べ沈水植物帯では区間全体として明ら かにより強い浄化型を示した. しかしながら植物の寄与 を抽出するとさほど大きくないという結果を得た．もち ろん植物量や付着物質量と直接の関係が得られなくとも， 植物の存在により河床環境が浄化型となっていることは 十分考えられるが，ここではそれを示すことはできない．

ところで，沈水植物帯では，抽水植物帯に見られるよ うな堆積物による顕著な河床の上昇は見られない.これ は沈水植物が抽水植物に較べ河床への固着力が弱く，増 水時には河床から剝離して流亡することによる. 仮に沈 
表-7 沈水植物帯における毎月調查結果の最小 2 乗近似による減少係数

\begin{tabular}{|l|c|c|cccccc|}
\hline & & $\begin{array}{c}\text { 相関 } \\
\text { 係数 }\end{array}$ & $k_{20}$ & $k_{20 p}$ & $k_{20 s}$ & $k_{t}$ & $k_{T_{p}}$ & $k_{T_{s}}$ \\
\hline 植物量のみ & $\mathrm{COD}$ & 0.14 & 0.218 & $1.67 \times 10^{-4}$ & - & 1.006 & 1.016 & - \\
を考慮 & $\mathrm{T}-\mathrm{N}$ & 0.14 & 0.876 & $6.89 \times 10^{-3}$ & - & 0.995 & 0.993 & - \\
& $\mathrm{T}-\mathrm{P}$ & 0.57 & 0.697 & $-5.31 \times 10^{-2}$ & - & 1.126 & 1.208 & - \\
\hline 植物量と & $\mathrm{COD}$ & 0.53 & 0.188 & $4.61 \times 10^{-4}$ & $-1.15 \times 10^{-4}$ & 0.977 & 1.0 & 0.757 \\
付着物量を & $\mathrm{T}-\mathrm{N}$ & 0.70 & 0.887 & $-9.93 \times 10^{-3}$ & $9.03 \times 10^{-2}$ & 1.042 & 1.931 & 1.518 \\
考虑 & $\mathrm{T}-\mathrm{P}$ & 0.63 & 0.539 & $-2.02 \times 10^{-2}$ & $8.87 \times 10^{-2}$ & 0.998 & 0.864 & 0.905 \\
\hline
\end{tabular}

(相関係数は、 $k_{20}, k_{T}, k_{20 p}, k_{T_{p}}, k_{20 s}, k_{T_{s}}$ により求めた $k$ と実測值よる $k$ の相関)

表-8 沈水植物帯に扔ける非水生植物項と沈水植物項 + 付着 物項の比, 沈水植物項と付着物項の比, および沈水植物 と付着物による污濁物質減少速度の年平均

\begin{tabular}{|c|c|c|c|}
\hline & $\begin{array}{c}\left(k_{20 p} k_{T_{p}}^{T-20} B_{p}+\right. \\
\frac{\left.k_{20 s} k_{T_{s}}^{T-20} B_{s}\right) / h}{k_{20} k_{T}^{T-20}}\end{array}$ & $\frac{k_{20 p} k_{T_{p}}^{T-20} B_{p}}{k_{20 s} k_{T_{s}}^{T-20} B_{s}}$ & $\begin{array}{l}\text { 沈水植物と何着 } \\
\text { 物による污濁物 } \\
\text { 質減少速度 } \\
{\left[g \cdot h r^{-1} \cdot m^{-3}\right]}\end{array}$ \\
\hline COD & 0.02 & -19.31 & $3.85 \times 10^{-3}$ \\
T-N & 0.86 & -0.22 & $3.89 \times 10^{-2}$ \\
T-P & -0.04 & -1.10 & $-3.05 \times 10^{-3}$ \\
\hline
\end{tabular}

水植物帯が平水時水質浄化に寄与しているとしても，栄 養塩を吸収した植物体や付着物が剝離・流下し，分解さ れることにより，結局は下流部に污濁物質をもたらすこ とになる。

このように考えると, 沈水植物帯は平水時水質に好影 響を与える可能性がある反面，管理が難しく，下流に対 する污濁物質総量の削減はあまり期待できないのではな いか.

\section{4. 結 論}

抽水植物帯, 沈水植物帯が河川水質に与える影響を実 河川において調査・解析した.

抽水植物帯においては植物体の成長に伴う栄養塩の吸 収により目に見えて水質浄化が起こっているように考え られがちであるが，平水時の水質浄化効果はほとんど認 められないばかりか, 水質悪化を招く場合すら見られた. 抽水植物は, 水体からではなく, もっぱら枯死した植物 体および堆積物からなる底泥から栄養塩を吸収している と考えられる. 抽水植物帯における主要な水質浄化作用 は増水時の懸濁物質堆積作用であると考え, 堆積物の浚 渫費を水処理費用と見立てて水処理コストを試算すると， 下水処理費用より安価となった. ただし, 河床を最大限 に利用しても污濁物質除去率は $15 \%$ 程度であり, 通水断 面の低下を伴うことを考えれば水質浄化法としての積極 的な利用はためらわれる.
一方, 沈水植物帯においては平水時水質の浄化作用が 認められた. しかし, 沈水植物帯では増水時に植物体や 付着物が容易に剝離・流下寸る. 剝離した植物体や付着 物は分解されることにより COD 増加に寄与するため、 下流域にかえって污濁負荷をもたらす可能性がある。こ のような意味で、沈水植物帯でも水質浄化作用を有効に 利用することは難しい.

以上の結果のみを考えると, 水質の浄化という観点か らは河川における抽水植物, 沈水植物の存在価值は評価 しにくいことになる。しかしながら，これをもって抽水 植物, 沈水植物の存在価值に疑問を呈するのは筆者らの 本意では決してない. 総生物量調査結果からも明らかな ように, 水生植物帯の生物の生息場としての側面を見落 としてはならない. 著者らのアンケート調査 ${ }^{24) に よ れ は ゙, ~}$ 市民は河川環境の重要な要素として水質ではなく魚をあ げている．水生植物帯を破壊すると魚が生息できなくな る可能性が高い. 水生植物帯は水質浄化の観点から論ず るより生態系の一部としての価值を論ずることが重要で あろう。

\section{5.あとがき}

筆者はDr. G. Freedrichi の自然型工法についての講演 会25)に参加する機会を得た. ドイッでは多様な生態系を 回復するため河岸に草や樹木を植えることが推奨されて いるとの話であった ${ }^{26)}$. 日本でもかっては害虫の発生を 防ぐため農家が自発的に河川の草刚りを行っていた．と ころが, 農薬の進歩によりもはや草刚りの必要がなくな り，現在ではほとんど行政の手にまかされている．この 結果，管理の面倒をなくすために河川をコンクリート三 面張としたり, 治水上問題になる寸前まで河岸や河床の 植物が放置されたりするのである.ドイッでは草の管理 はどうするのかとの筆者の質問に対して, Dr. Freedrichi からは「河川管理者 (River Authority) が草刈りや浚渫を する」という回答を得た. 講演会の参加者の多くは実際 に河川管理にあたっている行政担当者であったが，この 答えに失笑が起こっていた.この笑いは抢そらく,「日本 じゃ治水で手いっぱいなのに，さらに手の掛かるような 
工法は採用できないよ」という意味であろう．筆者はこ の笑いが日独の行政者の見識の違いをはっきり表してい ると考える.ドイツの行政者は, 河川の草刚りという面 倒を背負ってでも生態系を守っていくことが河川管理上 不可欠で重要な事項と認めているのである，また，それ が当然と受けとめるほど社会が成熟しているのである.

常に植物を管理し，堆積物を除去するといったきめの こまかい対策がとれるほどに社会が成熟すれば，抽水植 物，沈水植物が目に見えるような浄化の役割を担うこと もあるいは可能かもしれない.

謝辞：本研究は財団法人河川環境管理財団のご援助を 得た。記してここに謝意を表する。

\section{参 考 文 献}

1) 森忠洋・長川秀実：エコテクノロジーを活用した松江城 堀川の直接净化, 用水と廃水, Vol.32, No.8, pp. 686-691, 1990.

2) 今岡務・寺西靖治：ホテイアオイの成長速度と栄養塩吸 収特性に関する解析一とくに窒素について一, 衛生工学研 究論文集, Vol.19, pp. 109-115, 1983.

3) 小田中敏男: 水生植物による流水の浄化に関する研究, 東 京都立工科短期大学研究報告, Vol.14, pp. 145-156, 1986.

4) 本橋敬之助：ホテイアオイ植栽围場における水質の経時変 化一手賀沼を例にして一，水処理技術, Vol.33, No.4, pp. 185-192, 1992.

5) 新井洋一·大槻忠·名取真: リビング・フィルター 生物の 働きを利用した環境浄化, PPM, Vol.10, No.8, pp. 16-23， 1979.

6) 德永隆司: 水生植物の水質污濁防止への利用, 用水と廃水, Vol.23, No.2, pp. 127-135, 1981.

7) 小島貞男 : 自然の浄化力を利用した水質改善, 用水と廃水, Vol.24, No.1, pp. 5-12, 1982.

8）青山勲: 水生植物を利用した水質改善, 用水と廃水, Vol.24, No.1, pp. 87-94, 1982.

9) 細見正明:湿地による水質浄化, 用水と廃水, Vol.32, No.8, pp. 716-719, 1990.

10）細川恭史 ·三好英一・古川恵太：ヨシ原に上る水質浄化 の特性, 港湾技術研究所報告, Vol.30, No.1, pp. 205-237, 1991.

11) 名取真: 水生植物による排水処理, 環境技術, Vol.7, No.9, p. 87,1978 .
12) Reddy, K. R. and Busk, W. F. D.: Nutrient removal potential of selected aquatic macrophytes, Journal of Environmental Quality, Vol.14, No.4, pp. 459-462, 1985.

13）橋本奨・古川憲治·刑部忠彦: 鹿沼土と水生植物による 2 次処理水の高度処理に関する研究, 水道協会雑誌, Vol.57, No.4, pp. 47-54, 1988.

14）本部広哲・新納正也・上田耕三郎：ブラックマッペを用い た植物フィルターによる水中の空素・リンの除去, 用水と 廃水, Vol.32, No.6, pp. 486-490, 1990.

15）三島亨:水生植物による水域浄化システム,ヘドロ, Vol.33, pp. 43-50, 1985.

16) 福岡捷二・新井田浩・佐藤健二：才ギの河岸侵食抑制機 構と耐力の評価, 水工学論文集, Vol.36, pp. 81-86, 1992.

17）福岡捷二.甲村謙友・渡辺明英·三浦央晴: 船が造る波 のエネルギーを減衰させる河岸ヨシ原の効果, 水工学論文 集, Vol.36, pp. 713-716, 1992.

18）須藤隆一: 水域の直接浄化の意義と展望, 用水と廃水, Vol.32, No.8, pp. 663-667, 1990.

19）関根雅彦·山本修司·浮田正夫·中西弘:河川水質解析におけ る河床堆積物の評価一水草帯堆積物について一, 土木学会 第 40 回年次学術講演会講演概要集, Vol. 2, pp. 509-510, 1985.

20）関根雅彦・浮田正夫・中西弘・豊田商久：河川水質モデル における拡散の取扱いに関する一考察, 第 43 回土木学会 中国四国支部研究発表会講演概要集, pp. 138-139, 1991.

21）浮田正夫：わが国における窒素・りんの発生源構造と富 栄養化の機構に関する基礎的研究, 学位論文, 京都大学, 1983.

22）浮田正夫 · 中西弘：瀬戸内海への栄盖塩類の流入負荷解 析と対策, 瀬戸内海研究フォーラム in 広島瀬戸内海研究 会議, 1992.

23）関根雅彦：污濁負荷流出・流下モデルに基づく河川水質 予測手法に関する研究, 学位論文, 京都大学, 1991.

24）豊田商久·関根雅彦・浮田正夫 · 中西弘：アンケート調 査による河川に対する住民意識の解析, 土木学会第 46 回 年次学術講演会講演概要集, Vol. 2, pp. 244-245(II-102), 1991.

25) Friedrich, G.: ライン川に扔けるビオトープと自然型工 法, 1992. 28 Oct. 治水関係事業促進山口県大会記念講演 会 於 山口県視聴覚センター。

26) Friedrich, G. and Mueller, D.: Rhine, ECOLOGY OF EUROPEAN RIVERS (Ed. by Whitton, B. A.), Blackwell Scientific, Oxford ; Boston, pp. 265-316, 1984.

(1992. 12. 2 受付)

\section{EFFECT OF THE EMERSED PLANTS AND SUBMERGED PLANTS ON THE RIVER WATER QUALITY}

Masahiko SEKINE, Masao UKITA, Hiroshi NAKANISHI and Hisatake SHIROTA

Effect of the emersed plants and submerged plants on the river water quality was estimated based on the field survey. Concerning the emersed plants, it was revealed that they didn't purify the river water in ordinary water discharge period. The main cause of purification by the plants was the sedimentation in flood period. On the other hand , the submerged plants purified the river water in ordinary water discharge period. In flood period, however, they came off from the river bed and caused pollutant loads to the lower reaches. The merit of existence of aquatic plants in the river bed should not be estimated from the view point of water quality purification but from the view point of ecosystem conservation. 